Universidad de Lima

Facultad de Derecho

Carrera de Derecho

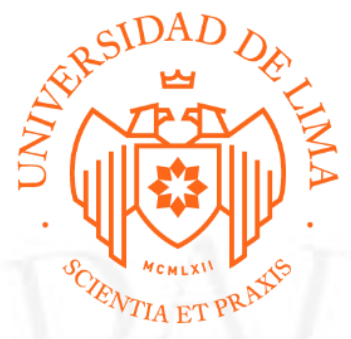

\title{
CIVIL: "OBLIGACIÓN DE DAR SUMA DE DINERO" Y ADMINISTRATIVO: "PROTECCIÓN AL CONSUMIDOR"
}

Trabajo de suficiencia profesional para optar el Título Profesional de Abogada

\author{
Kelly Karina Chávez Pérez
}

Código 20070247

Lima - Perú

Agosto de 2019 


\title{
CIVIL: "OBLIGACIÓN DE DAR SUMA DE DINERO"
}

Materia: Obligación de dar suma de dinero

$N^{o}$ de Expediente: 24464-2014-0-1801-JR-CI-33

\section{RESUMEN}

El demandante requiere el pago de tres guías aéreas internacionales a la demandada por los servicios de mensajería que le prestó. El demandante y el demandado acordaron que la destinataria de los servicios de mensajería efectuaría el pago de las guías aéreas internacionales, lo cual no ocurrió. En este contexto, el demandante interpone demanda de obligación de dar suma de dinero contra la demandada, toda vez que las guías aéreas internacionales debidamente suscritas por ella, prevén la responsabilidad de pago del remitente, es decir, la demandada, por todos los gastos del servicio de mensajería, incluso si el remitente hubiese dado instrucciones de pago distintas. Por su parte, la demandada reconoce la prestación de los servicios de mensajería, pero sostiene que no los contrató con el demandante, sino con un tercero conforme se desprende del contenido de las guías aéreas internacionales.

\section{ADMINISTRATIVO: "PROTECCIÓN AL CONSUMIDOR"}

\author{
Materia: Protección al consumidor \\ $\mathrm{N}^{\mathrm{o}}$ de Expediente: $663-2011 / \mathrm{CPC}$
}

\section{RESUMEN}

La denunciante al tomar conocimiento de once operaciones bancarias que se efectuaron con cargo a su cuenta de ahorros sin su autorización, bloqueó su tarjeta de débito y presentó una carta al denunciado requiriendo información detallada de lo sucedido. Ante la falta de una respuesta, la denunciante presentó ante Indecopi una denuncia por infracción al deber de idoneidad en las medidas de seguridad que ofrece el denunciado como por infracción al deber de información al no haber dado respuesta el denunciado al requerimiento de información. A consecuencia de la transacción extrajudicial celebrada entre las partes, la denunciante presentó el desistimiento de la denuncia en segunda instancia, el cual fue acogido solo en parte por la Sala. 